\title{
Overviewing and Analyzing of Intangible Resources of Food Industry SMEs in Surabaya - Indonesia
}

\author{
Oliandes Sondakh \\ Business School, Universitas Pelita Harapan, Surabaya Campus, Indonesia
}

\begin{abstract}
Entering the era of free trade, Small and Medium Enterprises (SME) is seen to have strategic role in pushing the economy growth of a country. Concept of how companies could achieve their excellence performance through the utilization of resources or well known as Resources based View (RBV). RBV explains the concept of organization performance through the focus on internal resources owned by companies. This research study was a crosssectional survey of food industry SMEs in Surabaya. The proposed study population comprised of 112 SMEs. Based on the average of respondent's answer for Organizational Resources, it is known that the respondents, who are the owners of SMEs food industry in Surabaya, assess their ownership of Organizational Resources is high. Managerial Resources is rated as the highest resources, followed with Technical Resources, while Marketing Resources is rated relatively low. Future research could expand the dimensions of resources into tangible resources, in order to have a complete overview of resources of food industry SMEs.
\end{abstract}

Keywords: Resources based View, Managerial Resources, Technical Resources, Marketing Resources

DOI: $10.7176 / \mathrm{EJBM} / 11-17-07$

Publication date:June $30^{\text {th }} 2019$

\section{Introduction}

Entering the era of free trade, Small and Medium Enterprises (SME) is seen to have strategic role in pushing the economy growth of a country (Husband \& Purnendu, 1999; Mahemba, 2003; Tambunan, 2005). Some empirical research show that SMEs do not only function as an economy driving force, but also as a source of field work creation (Collinson \& Houlden, 2005). This is why it is important for policy maker to focus on factors that can support SMEs competitive advantage, which one of it is resources.

Concept of how companies could achieve their excellence performance through the utilization of resources or well known as Resources based View (RBV) were first introduced by Barney in 1991. RBV explains the concept of organization performance through the focus on internal resources owned by companies (Grant, 1991, Harrison \& St. John, 1994). In RBV's view, organizational performance and competitive advantage are achieved through a unique combination of scarce, elusive, and valuable resources for the achievement of the specific objectives of the enterprise (Barney, 1986).

In general, Barney and Hesterly (2006) argue that resources can be classified into two, namely: tangible resources and intangible resources. Tangible resources consists things like capital, buildings, warehouses, and other facilities, while the intangible resources consist of knowledge, skills and reputation. Furthermore, some studies suggest that intangible resources have more contribution than tangible resources in creating organizational values (Itami 1987; Amit \& Schoemaker, 1993; Hitt et al., 2001). This is because intangible resources are generally more difficult to replicate, transfer or replace, which are the characteristic of valuable and scarce resources, which is a requirement for the creation of competitive advantage (Barney, 1991). This concept support by research conducted by David (2011), who found that organizational performance is predominantly determined by internal corporate resources, such as employees, training, experience, intelligence, knowledge, skills, capabilities, information systems, patents, trademarks, copyright, database, and so forth.

Further, Fitz-en (2000 in Fathi et al., 2013) states that the business world has undergone a shift from a production-based (traditional) economy to a knowledge-based economy. Cash, buildings, and equipment, can no longer be considered as a differentiator in competitive advantage. Therefore, SMEs should recognize the importance of knowledge-based businesses by optimizing their intangible resources, while on the field, phenomenon shows that most SMEs do not apply the system of organization and management commonly applied in the modern business world. Many small businesses where owners do all activities: production; procurement of raw materials; marketing; and administration; traditionally (Tambunan, 2010). This is what causes various problems in the internal SMEs.

Hafsah (2004) mentioned there are some internal problems faced by SMEs: lack of capital; limited human resources; and weak business networks. This is also supported by Tambunan (2008) which states that the main cause of low productivity of SMEs in Indonesia (and in developing countries in general) is the limitations of technology and human resources. Fajar (2009 in Kautsar, 2011) added that the problems faced by SMEs are the lack of quality of capital, marketing, lack of knowledge, and human resources, besides the mastery of knowledge that becomes an important factor in improving the competitiveness of SMEs. This lack of mastery of knowledge is the biggest weakness for SMEs. Though mastery of knowledge is the key to winning the competition. Mastery 
of knowledge can be realized in the form of mastery of technology knowledge, work methods and work culture. Furthermore, Tambunan (2010) states that the competitiveness of a company is determined by seven factors, namely: skill or education level of workers; expertise of employers; availability of capital; good organizational and management systems; availability of technology; availability of information; and the availability of other inputs. This is supported also by Widiastuti and Sulistyandari (2013) stating that SMEs that have high competitiveness are characterized by reliable human resources capability, high knowledge mastery, and economic control.

\section{Literature Review}

\subsection{Resources based View}

Resource-Based Views (RBV) are considered as dominant perspectives other than the perspective of Industrial Organization in the field of Strategic Management. This is because companies are defined as "a set of activities" in the perspective of the Industrial Organization's view, while in Resource-Based Views; firms are regarded as "a collection of resources" (Spanos \& Lioukas, 2001).

Penrose was one of the first academics to introduce the importance of the RBV in 1959, while Wernerfelt (1984) examines this view more deeply and discusses how resources can affect organizational performance. The product is something that really determines the performance of the organization, and production depends heavily on the company's resources. Therefore, this theory views resources and products as "two sides of the same coin". The RBV is based on the assumption that resources provide competitive advantage through the level of resource importance in product marketing strategies.

RBV has been evolved by Barney (1991) who discussed Porter's Five Forces model and how to describe organizational performance through environmental conditions and industry attributes. It is stated that although the SWOT framework (Strength, Weakness, Opportunity, and Threat) analyzes both internal and external factors, the focus of most companies is still related to opportunities and threats. Though corporate attributes are something more important than the industrial aspect, and the resources become decisive in the company's competitive position. Thus, RBV are based on the basic assumption that resources are factors that can lead to competitive advantage, and the resources that can create competitive advantage are heterogeneous and immobile resources.

RBV stem from the principle that the source of the company's competitive advantage lies in the company's internal resources. Where instead of evaluating the opportunities and threats that exist in the environment, competitive advantage depends on the resources and capabilities that the company has (Barney, 1995). RBV estimate that certain types of resources owned and controlled by firms, have the potential to generate competitive advantage, and ultimately lead to superior organizational performance. Thus, RBV are considered to have an "outward" view, where a company's resources are seen as factors that can provide competitive advantage (Barney, 1991).

\subsection{Resources Characteristics}

According to Barney's (1991) framework, companies with competitive advantage will be able to improve organizational performance, and competitive advantage can be obtained when the resources they own are valuable, rare, inimitable and non-substitutable. The valuable resources enable companies to implement strategies that can improve efficiency and effectiveness. A valuable resource will be able to help the company take advantage of opportunities and neutralize threats. The scarcity of resources is related to ownership. If a large number of competitors have the same resources, resources cannot be considered scarce, and therefore cannot be a source of competitive advantage. Therefore a company's resources must be unique when compared to competitors' resources. A resource can also be considered scarce when the number of companies with such valuable resources is less than the number of companies that need it, and thus create perfect competition. In order for a resource to provide a competitive advantage, the next important thing is ensured that competitors cannot copy or replicate the resource. The last criterion is that there is no substitute for the company's unique resources. If other companies have similar resources, or provide an equivalent strategic position, there will be no competitive advantage to be gained.

RBV expressed by Barney (1991) were criticized for their static nature. Mahoney and Pandian (1992) argue that valuable, scarce, inimitable, and irreplaceable resources cannot guarantee superior organizational performance. Understanding that performance improvement relies on the ability and competence of the company, to exploit resources in such a way, so that productivity can be optimized. This is supported also by Peteraf (1993) and Henderson and Cockburn (1994), and based on that, Barney (2002) recognizes that the framework is less exploitative, and therefore introduces well-organized resource criteria (The "O" in VRIO / Valuable, Rare, Inimitable and Organized). Where these criteria ensure how the company can take full advantage of resources through organizing resources.

\subsection{Intangible Resources}

According to RBV outlook, organizational performance differences are mainly due to differences in company 
resource ownership, especially intangible resources, because intangible resources are generally difficult to obtain or develop, duplicate or accumulate, and imitated by competitors (Wernerfelt, 1984; Dierickx \& Cool, 1989; Barney, 1991). Intangible resources generally do not have universally acceptable definitions. However, there are similar characteristics of some definitions of intangible resources. Intangible resources are non-physical resources, resources that have potential sources of future economic benefits, and resources that can be reached and traded at some level (OECD 2006).

Intangible resources include research and development ( $\&$ \& $)$, patents, trademarks, capabilities and human resources, organizational competencies (such as databases and technology), relationship capital (e.g. with customer and supplier networks), and design and organizational processes (OECD 2006). Among the many intangible resources, Gomez-Mejia and Balkin (2002) place technology, humanity and reputation as the three most important strategic resources, while Barney (1986) and Grant (1991), add by incorporating culture as a strategic resource.

Hendriksen and Van Breda (in Chiarello et al., 2014) define intangible resources as untouchable resources for lack of physicality. Intangible resources are viewed as the company's dynamic capacity, composed by knowledge, organizational structure, innovative capacity, brand, research and development, and market share (Tsai et al., 2012). From the point of view of Lev (2001), intangible resources are the source of value without physical substance. Intangible resources are generated by innovation, unique organizational projects, and human resource practices, and thus become an important source of differentiation and competitiveness.

\section{Research Methodology}

Research design constitutes the blue print for collection, measurement, and analysis of data. This research study was a cross-sectional survey of food industry SMEs in Surabaya. The proposed study population comprised of 112 SMEs. This is because in accordance with the research objectives that have been proposed, this research uses purposive sampling technique, where this technique requires the way sampling based on certain criteria. The sampling criteria used in this study are:

1. Located in Surabaya

2. The age of SME is $\geq 3$ years

SMEs are a vulnerable type of business, and have a high failure rate. More than $70 \%$ of SMEs failed during the first three years of their operations. Statistics show that eight out of ten new ventures fail within the first three years. On that basis, according to the research objectives to be achieved, this study took a sample of SMEs that have stood for more than three years.

3. Categorized as medium-sized enterprises

The smaller the organization, the more difficult it is to determine its limits. Small businesses, consisting of one or several people, are generally composed of the same family members, and strongly influenced by family inheritance, making it vulnerable to bias. On that basis, in accordance with the research objectives to be achieved, this study took a sample of SMEs with medium scale.

Based on data from the Central Bureau of Statistics, the number of food industry SMEs in accordance with the characteristics established in the area of Surabaya is as many as 112 SMEs. This study in determining the number of samples using Slovin formula:

$\mathrm{n}=\frac{\mathrm{N}}{1+\mathrm{Ne} 2}$

Where:

$\mathrm{n}=$ number of sample

$\mathrm{N}=$ population size

$\mathrm{e}=$ level of error

In this research the value of e is $5 \%$, so the minimum sample amount used by researchers is 88 SMEs.

Questionnaires were used to collect primary data and the respondents were the owner / general managers in each of the firms. The questionnaires were administered using drop and pick later method.

The results of the survey were analyzed using descriptive statistics of mean and standard deviation to interpret the 5-point Likert scale type responses. Each element of the four elements of the balance scorecard were analyzed using frequencies and percentages to enable independent assessment of the effectiveness of each element as well as appraise the overall effectiveness of the tool in the industry. 


\section{Findings and Discussion}

\subsection{Findings}

\begin{tabular}{|c|c|c|c|c|}
\hline Dimensions & Indicators & $\begin{array}{c}\text { Pearson } \\
\text { Correlation }\end{array}$ & $\begin{array}{l}\text { Sig. }(2 \\
\text { tailed })\end{array}$ & Statement \\
\hline \multirow{6}{*}{$\begin{array}{l}\text { Managerial } \\
\text { Resources } \\
\text { (X1) }\end{array}$} & $\begin{array}{l}\text { The company is supported by competent managerial } \\
\text { team (X1.1) }\end{array}$ & 0.655 & 0.000 & Valid \\
\hline & The company is supported by skilled employees (X1.2) & 0.551 & 0.000 & Valid \\
\hline & $\begin{array}{l}\text { The company has a strong organizational culture } \\
\text { (X1.3) }\end{array}$ & 0.651 & 0.000 & Valid \\
\hline & $\begin{array}{l}\text { The company has an efficient organizational structure } \\
\text { (X1.4) }\end{array}$ & 0.475 & 0.000 & Valid \\
\hline & The company has the ability to coordinate $(\mathrm{X} 1.5)$ & 0.669 & 0.000 & Valid \\
\hline & $\begin{array}{l}\text { The company has the ability to carry out strategic } \\
\text { planning (X1.6) }\end{array}$ & 0.689 & 0.000 & Valid \\
\hline \multirow{3}{*}{$\begin{array}{c}\text { Marketing } \\
\text { Resources } \\
\text { (X2) }\end{array}$} & The company has qualified market knowledge (X2.1) & 0.642 & 0.000 & Valid \\
\hline & $\begin{array}{l}\text { The company has access to the right distribution } \\
\text { channel (X2.2) }\end{array}$ & 0.697 & 0.000 & Valid \\
\hline & $\begin{array}{l}\text { The company has special relationship with customers } \\
\text { (X2.3) }\end{array}$ & 0.371 & 0.000 & Valid \\
\hline \multirow{3}{*}{$\begin{array}{c}\text { Technical } \\
\text { Resources } \\
\text { (X3) }\end{array}$} & $\begin{array}{l}\text { The company has effective and efficient production } \\
\text { department (X3.1) }\end{array}$ & 0.422 & 0.000 & Valid \\
\hline & The company has good technical skills (X3.2) & 0.688 & 0.000 & Valid \\
\hline & $\begin{array}{l}\text { The company has modern technology and equipment } \\
\text { (X3.3) }\end{array}$ & 0.677 & 0.000 & Valid \\
\hline
\end{tabular}

Validity test is done through Pearson Product Moment Correlation test. The test result showed that the Pearson Product Moment Correlation value between each indicator with total scores of the variable yields a significance value of $\leq 0.05(\alpha=5 \%)$, so it can be concluded that all the indicators tested in this study are valid and thus all the indicators (statements used in the questionnaire) are representative in measuring Organizational Resources.

Table 1. Cronbach Alpha Test

\begin{tabular}{|l|l|l|}
\hline Variable & Cronbach Alpha & Statement \\
\hline Organizational Resources & 0,837 & Reliable \\
\hline
\end{tabular}

Reliability test is done through Cronbach Alpha test. The test result showed that the Cronbach Alpha value yields a value of $\geq 0.6$, so it can be concluded that all the indicators tested in this study are reliable and thus all the indicators (statements used in the questionnaire) are consistent in measuring the variable.

Organizational Resources in this research is consist of three composite variables, namely: Managerial Resources, Marketing Resources, and Technical Resources.

Table 3. Description Of Respondents Answer For Organizational Resources

\begin{tabular}{|l|l|l|l|}
\hline No. & Dimensions & Mean & Statement \\
\hline X1 & Managerial Resources & 3,89 & Agree \\
\hline X3 & Technical Resources & 3,85 & Agree \\
\hline X2 & Marketing Resources & 3,78 & Agree \\
\hline \multicolumn{2}{|l|}{ Rata-rata } & 3,84 & Agree \\
\hline
\end{tabular}

Table 3 shows that the average of respondent's answer for Organizational Resources variable is 3.84 with the agreed category, which means that on average, the respondents, who are the owners of SMEs food industry in Surabaya, assess their ownership of Organizational Resources is high. Managerial Resources is rated as the highest resources, with the average value of 3.89, followed with Technical Resources with the average value of 3.85, while Marketing Resources is rated relatively low, with the average value of 3.78 .

4.1.1 Managerial Resources

Managerial Resources consist of three indicators. Assessment of each indicator is presented in Table 4. 
Table 4. Description of Respondents Answer for Managerial Resources

\begin{tabular}{|c|l|l|l|l|l|l|l|l|l|}
\hline No. & \multicolumn{1}{|c|}{ Indicators } & \multicolumn{3}{|c|}{ Arequencies } & Average & Statement & $\begin{array}{c}\text { Std. } \\
\text { Dev }\end{array}$ \\
\cline { 3 - 8 } X1.5 & The company has the ability to coordinate & 0 & 0 & 20 & 42 & 26 & 4,07 & Agree & 0,724 \\
\hline X1.2 & $\begin{array}{l}\text { The company is supported by skilled } \\
\text { employees }\end{array}$ & 0 & 0 & 18 & 47 & 23 & 4,06 & Agree & 0,684 \\
\hline X1.6 & $\begin{array}{l}\text { The company has the ability to carry out } \\
\text { strategic planning }\end{array}$ & 0 & 0 & 29 & 39 & 20 & 3,90 & Agree & 0,743 \\
\hline X1.4 & $\begin{array}{l}\text { The company has an efficient organizational } \\
\text { structure }\end{array}$ & 0 & 2 & 24 & 47 & 15 & 3,85 & Agree & 0,720 \\
\hline X1.3 & $\begin{array}{l}\text { The company has a strong organizational } \\
\text { culture }\end{array}$ & 0 & 0 & 32 & 41 & 15 & 3,81 & Agree & 0,709 \\
\hline X1.1 & $\begin{array}{l}\text { The company is supported by competent } \\
\text { managerial team }\end{array}$ & 0 & 0 & 40 & 39 & 9 & 3,65 & Agree & 0,662 \\
\hline Mean
\end{tabular}

Table 4 shows that the average of respondent's answer for Managerial Resources composite variable is 3.89 with the agreed category, which means that on average, the respondents, who are the owners of SMEs food industry in Surabaya, assesses the company ownership of Managerial Resources is high.

For each indicator, the result of respondent's answer for Managerial Resources composite variable shows that on average, the respondents, who are the owners of SMEs food industry in Surabaya, consider the ability of the company to coordinate is high; with the average value of 4.07; which is also the highest value for Managerial Resources composite variable. The Company ownership of skilled employees and ability to carry out strategic planning are also consider high, with the average value of 4.06 and 3.90 respective. However, the company ownership of efficient organizational structure and strong organizational culture are still rated relatively low; with the average value of 3.85 and 3.81 respectively. The ownership of competent managerial team is rated as the lowest; with the average value of 3.65 .

4.1.2 Marketing Resources

Marketing Resources consist of three indicators. Assessment of each indicator is presented in Table 5.

Table 5. Description of Respondents Answer for Marketing Resources

\begin{tabular}{|c|l|l|l|l|l|l|l|l|l|l|l|}
\hline No. & \multicolumn{3}{|c|}{ Indicators } & \multicolumn{3}{|c|}{ Average } & Statement & $\begin{array}{l}\text { Std. } \\
\text { Dev }\end{array}$ \\
\cline { 3 - 9 } X2.3 & $\begin{array}{l}\text { The company has special relationship with } \\
\text { customers }\end{array}$ & 0 & 0 & 30 & 40 & 18 & 3,86 & Agree & 0,730 \\
\hline X2.2 & $\begin{array}{l}\text { The company has access to the right } \\
\text { distribution channel }\end{array}$ & 0 & 0 & 38 & 32 & 18 & 3,77 & Agree & 0,769 \\
\hline X2.1 & $\begin{array}{l}\text { The company has qualified market } \\
\text { knowledge }\end{array}$ & 0 & 3 & 31 & 42 & 12 & 3,72 & Agree & 0,742 \\
\hline Mean
\end{tabular}

Table 5 shows that the average respondent's answer for Marketing Resources composite variable is 3.78 with the agreed category, which means that on average, the respondents, which are the owners of SMEs food industry in Surabaya, assesses the company ownership of Marketing Resources is high.

For each indicator, the result of respondent's answer for Marketing Resources composite variable shows that on average, the respondents, who are the owners of SMEs food industry in Surabaya, considers that the company's relationship with their customers is special; with the average value of 3.86; which is also the highest value for Marketing Resources composite variable. However, the company's access to the right distribution channel is still rated relatively low, with the average value of 3.77. The ownership of qualified market knowledge is rated as the lowest; with the average value of 3.72 .

4.1.3 Technical Resources

Technical Resources consist of three indicators. Assessment of each indicator is presented in Table 6.

Table 6. Description of Respondents Answer for Technical Resources

\begin{tabular}{|c|l|l|l|l|l|l|l|l|l|l|l|}
\hline No. & \multicolumn{1}{|c|}{ Indicators } & \multicolumn{3}{|c|}{ Arequencies } & Average & Statement & $\begin{array}{c}\text { Std. } \\
\text { Dev }\end{array}$ \\
\cline { 3 - 9 } X3.2 & The company has good technical skills & 0 & 0 & 21 & 52 & 15 & 3,93 & Agree & 0,640 \\
\hline X3.1 & $\begin{array}{l}\text { The company has effective and efficient } \\
\text { production department }\end{array}$ & 0 & 0 & 21 & 55 & 12 & 3,90 & Agree & 0,607 \\
\hline X3.3 & $\begin{array}{l}\text { The company has modern technology and } \\
\text { equipment }\end{array}$ & 3 & 2 & 29 & 36 & 18 & 3,73 & Agree & 0,931 \\
\hline Mean
\end{tabular}


Table 6 shows that the average respondent's answer for Technical Resources composite variable is 3.85 with the agreed category, which means that on average, the respondents, who are the owners of SMEs food industry in Surabaya, assesses the company ownership of Technical Resources is high.

For each indicators, the result of respondent's answer for Technical Resources composite variable shows that on average, the respondents, who are the owners of SMEs food industry in Surabaya, considers that the company's technical skills is good; with the average value of 3.93; which is also the highest value for Technical Resources composite variable. Production department is also rated relatively effective and efficient, with the average value of 3.90. The ownership of modern technology and equipment are rated lowest; with the average value of 3.73.

\subsection{Discussion}

\begin{tabular}{|c|c|c|c|}
\hline $\begin{array}{l}\text { Latent } \\
\text { Variable }\end{array}$ & $\begin{array}{l}\text { Composite } \\
\text { Variable }\end{array}$ & Indicators & $\begin{array}{l}\text { Outer } \\
\text { Loading }\end{array}$ \\
\hline \multirow[t]{12}{*}{ Resources } & \multirow{6}{*}{$\begin{array}{l}\text { Managerial } \\
\text { Resources }\end{array}$} & The company is supported by competent managerial team (X1.1) & 0,705 \\
\hline & & The company is supported by skilled employees (X1.2) & 0,618 \\
\hline & & The company has a strong organizational culture (X1.3) & 0,721 \\
\hline & & The company has an efficient organizational structure (X1.4) & 0,584 \\
\hline & & The company has the ability to coordinate (X1.5) & 0,819 \\
\hline & & The company has the ability to carry out strategic planning (X1.6) & 0,740 \\
\hline & \multirow{3}{*}{$\begin{array}{l}\text { Marketing } \\
\text { Resources }\end{array}$} & The company has qualified market knowledge (X2.1) & 0,873 \\
\hline & & The company has access to the right distribution channel (X2.2) & 0,870 \\
\hline & & The company has special relationship with customers (X2.3) & 0,507 \\
\hline & \multirow{3}{*}{$\begin{array}{l}\text { Technical } \\
\text { Resources }\end{array}$} & The company has effective and efficient production department (X3.1) & 0,637 \\
\hline & & The company has good technical skills (X3.2) & 0,818 \\
\hline & & The company has modern technology and equipment (X3.3) & 0,801 \\
\hline
\end{tabular}

Table 8. $t$-Statistics for Composite Variable

\begin{tabular}{|l|l|l|l|l|}
\hline Latent Variable & Composite Variable & Koef. Path & t-stat & Statement \\
\hline \multirow{4}{*}{ Resources } & Managerial Resources (X1) & 0,863 & 25,630 & Sig. \\
\cline { 2 - 5 } & Marketing Resources (X2) & 0,773 & 20,744 & Sig. \\
\cline { 2 - 5 } & Technical Resources (X3) & 0,845 & 31,434 & Sig. \\
\hline
\end{tabular}

Duncan (1972) and Williams (2009) defined internal environment as a whole factors within the company that affect the company's capacity to develop and implement a feasible plan, in order to achieve its intended goals, and at the end it is expected to increase the company's performance. These factors consists of: Managerial Resources, Technical Resources, and Marketing Resources.

The results of data analysis show that company's resources are best reflected by Managerial Resources, followed by Technical Resources, and last by Marketing Resources. Managerial resources play the most important role, because Managerial Resources allow company to operate at a strategic level. Managerial resources are obtained based on the knowledge and the experience of the company, so compare to other resources, Managerial Resources is perceived as a unique resources that will not easily to imitate by competitors (Penrose, 1959; Katz, 1974; Hambrick \& Mason, 1984; Norburn \& Birley, 1988; Barney, 1991; Castanias \& Helfat, 1991; Finkelstein \& Hambrick, 1996).

On the other hand, a tight and dynamic competition requires companies to adapt their operational processes to market developments (Bo lívar-Ramos et al., 2012) in order to achieve an effective and an efficient operational processes (Salama, 2017). This is why Technical Resources is the second best variable in reflecting the company's resources.

Marketing resources is the last variable in reflecting company's resources. This is because the success of company is not only determined by the collaboration between the company and their downstream network but is also by the collaboration with their upstream network (Huo, 2012; Xu et al., 2014).

Results of the respondents' answers indicate that on average, the owner of SMEs food industry in Surabaya assesses the resources owned by the company is on high-level. This is because majority of the SMEs who are became the respondents in this study have been established their business for more than five years, so the company's internal environment is perceived to be solid and able to run automatically. This is also supported by the knowledge management that carried out by the company in order to bring a breakthrough in the production process. This is why Managerial Resources is rated as the highest resources, followed by Technical Resources. While Marketing Resources is perceived as a relatively lower resources, because even though the downstream party is an inseparable part of the company's supply chain, but it is not easily control by the company because the process required participation from both parties. 
Managerial resources can be defined as the average perception of the owners of SMEs food industry in Surabaya on company's processes and managerial aspect owned and controlled by company. Managerial resources consist of company ownership of competent managerial team, skilled employees, strong organizational culture, and an efficient organizational structure, and company ability to coordinate, and to carry out strategic planning.

Based on outer loading factor, it is known that the variable of Managerial Resources is best reflected by the indicator of the company has the ability to coordinate, followed by the indicator of the company has the ability to carry out strategic planning, the indicator of the company has a strong organizational culture, the indicator of the company is supported by competent managerial team, the indicator of the company is supported by skilled employees, and finally the indicator of the company has an efficient organizational structure.

Food industry is a labor intensive industry (Ministry of Industry of the Republic of Indonesia, 2017). When company grow from a micro scale to small and medium scale, it means that the number of employees will also be increase, and requires company to have the ability to coordinate. Coordination is the process of integrating functions, structures, and resources in the context of an organization (Viinamäki, 2004). When company has the ability to coordinate, synchronizing of every management function within the company will occurs actively and directly towards achieving the company's goals. Good coordination will help company to reduce the cost of time, money, and effort, and at the same time increase the efficiency and the effectiveness of a process, and also morale of employees (Enright, 1992; Viinamäki, 2004; Kramer, 2010). Coordination is especially important for dealing with challenges that occur inside and outside the company (Viinamäki, 2004). This is why the indicator of the company has the ability to coordinate is the best indicator in reflecting the composite variable of Managerial Resources.

Furthermore, tight and dynamic competition requires companies to adjust their operational processes to market developments (Bolvar-Ramos et al., 2012), and thus require companies to have the ability to carry out strategic planning and strong organizational culture, in order to maintain harmonization of company and environment. Strategic planning is part of company's coordinative framework, which is expected to enrich and explore broader and more profitable policies and activities, to achieve better performance (Lewis, 2006). On the other hand, a strong organizational culture is one tool that can be used to overcome environmental uncertainties. As a labor intensive industry, companies engaged in food industry will have employees from various backgrounds, culture, and traditions that form their personality. Having a strong organizational culture at work will giving a sense of unity and mutual understanding between one and another, promoting better communication, and reducing conflict; and by the end, it is expected to produce strong commitment to the organization (Boon \& Arumugam, 2006; Manetje \& Martins, 2009; Zain et al., 2009; Lauture et al., 2012; Ghorbanhosseini, 2013) and ultimately will increase company performance (Bonaparte, 2008; Dost et al., 2011; Kashefi et al., 2013; Irefin \& Mechanic, 2014). This is why the indicator of the company has the ability to carry out strategic planning and the indicator of the company has a strong organizational culture are the second and third best indicator in reflecting the composite variable of Managerial Resources.

Furthermore, because food industry is a labor-intensive industry (Ministry of Industry of the Republic of Indonesia, 2017), then it means that to regulate their employees, the company must have a competent managerial line. Managerial competence is not a skill that can be defined and measured clearly and objectively. In contrast, managerial competence is a situational, contextual and socially constructed skill (Boyatzis, 2008), and therefore is a unique skill. This competency will enable the company's managerial team to run a business. On the other hand, employee competency is usually related to technical skills which include the knowledge of methods, processes, and equipment used to produce products with quality. This type of expertise is obtained through a combination of formal education, training, and working experience (Pate et el., 2003; Ozcelik \& Ferman, 2006). Ownership and utilization of knowledge and capabilities from both managerial and employees can lead to the creation of competitive advantage for companies (Ozcelik \& Ferman, 2006). This is why the indicator of the company is supported by competent managerial team and the indicator of the company is supported by skilled employees are the fourth and fifith best indicator in reflecting the composite variable of Managerial Resources.

Finally, the organizational structure describes the division, commando, and coordination of tasks within the company (Sablynski, 2003). Without a clear organizational structure, employees may be find it difficult to know to whom they should report and be formally responsible (Teixeria et al., 2012). An efficient and not long-winded organizational structure will provide guidance and clarity to each employee at all levels regarding their respective roles in the company, and thus produce more productive work. However, a clear organizational structure may encourage employees to act only in their accordance role and became less pro-active. This is why the indicator of the company has an efficient organizational structure is the least indicator in reflecting the composite variable of Managerial Resources.

Based on descriptive value of respondents' answers on the composite variable of Managerial Resources, it is known that the highest indicator perceived by the respondents is the indicator of the company has the ability to coordinate, the indicator of the company is supported by skilled employees, the indicator of the company has the ability to carry out strategic planning, the indicator of the company has an efficient organizational structure, the 
indicator of the company has a strong organizational culture, and finally the indicator of the company is supported by competent managerial team.

It can be explained that since the majority of the owners of SMEs food industry in Surabaya who were respondents in this study has established their business for more than five years, so in average they perceived that coordination is no longer a new thing in their company. The company already has experiences in dealing with various problems and conflicts and manage to solve it. This is because coordination has become part of daily activities of company and also because company is supported by skilled employees. All those resources enable the company to withstand environmental changes, and therefore has experience in managing the company's strengths and weaknesses, to seize opportunities and overcome challenges. This experience allowed the company to implement it in the form of a qualified strategic planning. This is why the indicator of the company has the ability to coordinate, followed by the indicator of the company is supported by skilled employees, and the indicator of the company has the ability to carry out strategic planning are perceived as the three highest indicators for Managerial Resources composite variable.

On the other hand, because the majority of the owners of SMEs food industry in Surabaya who were respondents in this study has established their business for more than five years, so in average they perceived that their company already has the experience that makes the company able to sort out the functional/department that is needed and that is not needed, so company can operate efficiently. This is also supported by a strong organizational culture that built within the company. The process of cultural assimilation in employees causes organizational culture to become part of daily habits. This is why the indicator of the company has an efficient organizational structure and the indicator of the company has a strong organizational culture are perceived as the fourth and fifth indicators for Managerial Resources composite variable.

The lowest indicator perceived by the owners of SMEs food industry in Surabaya is the indicator stated that the company is supported by skilled employees. This is because the owners of SMEs food industry in Surabaya still perceived that their managerial team cannot be compared with managerial team from large company. Large company is perceived to have more resources in recruiting top managerial teams. However, even though it is perceived as the lowest, this indicator is still on high value, which means that it is still perceived as a sufficient resources. This is because even though the managerial team owned by SMEs food industry in Surabaya is not the top managerial but still perceived to have sufficient competence to run a business based on their experience.

Technical resources can be defined as the average perception of the owners of SMEs food industry in Surabaya on the technical systems owned and controlled by company, including the company's ability to transform inputs into outputs. Technical resources consist of company ownership of an effective and an efficient production departments, technical skills, and modern technology and equipment.

Based on outer loading factor, it is known that the composite variable of Technical Resources is best reflected by the indicator of the company has technical skills, followed by the indicator of the company has modern technology and equipment, and finally the indicator of the company has effective and efficient production department.

Technical skills refer to a skill that a person must mastering in order to do certain work that cannot be done by ordinary people and requires special expertise in the form of theoretical and practical knowledge (Pate et el., 2003; Ozcelik \& Ferman, 2006). Technical skills are consider as valuable assets for company that engaged in food industry because technical skills are useful to ensure the operation of company in order to run effectively and efficiently, and minimize waste that occurs during the operation processes. Technical skills allow employees to communicate effectively both vertically and horizontally. This is why the indicator of the company has technical skills is the best indicator in reflecting the composite variable of Technical Resources.

Furthermore, company engaged in the food industry is also required to have modern technology and equipment. Technology is a broad concept refer to the breakthroughs in science that enable better or automated solutions (Utterback, 1994). The most obvious benefit of the use of technology for companies engaged in food industry is the increasing of productivity, which is translated into lower cost structures, higher production speed, easiness of sharing and storing information, and decreasing in the level of human error through the process of automation, which at the end resulting in decreasing of cost and increasing of income. This is why the indicator of the company has modern technology and equipment is the best second indicator in reflecting the composite variable of Technical Resources.

Finally, even though companies engaged in the food industry is required to have an effective and efficient production department, the most important thing is actually the integration between the choice of facilities and technology with the operations of the company and employees (Hayes \& Wheelwright, 1984). Organizational performance can only be achieved if the company has the ability to integrate company's operations with the company's business strategy. This is why the indicator of the company has effective and efficient production department is the least indicator in reflecting the composite variable of Technical Resources.

Based on descriptive value of respondents' answers on the composite variable of Technical Resources, it is known that the highest indicator perceived by the respondents is the indicator of the company has technical skills, 
followed by the indicator of the company has effective and efficient production department, and finally the indicator of the company has modern technology and equipment.

It can be explained that since the majority of the owners of SMEs food industry in Surabaya who were respondents in this study has established their business for more than five years, so in average they perceived that their employees already have a lot of experience and therefore assume to have qualified technical skills. The experience that the employees have enable them to work independently, effectively, and efficiently, and at the end it is expected to lead to more productive operations. The company's production department is also perceived to have competencies in handling the company's operations processes, starting from planning, implementing, until controlling in order to produce the best products to meet customer needs. This is why the indicator of the company has technical skills, followed by the indicator of the company has effective and efficient production department are perceived as the two highest indicators for Technical Resources composite variable.

The lowest indicator perceived by the owners of SMEs food industry in Surabaya is the indicator stated that the company has modern equipment and technology. This is because the owners of SMEs food industry in Surabaya still perceived that their company has limited capital compared to large companies, so the technology and equipment owned by them may not be as sophisticated as the technology and equipment owned by large companies. However, even though it is perceived as the lowest, this indicator is still on high value, which means that it is still perceived as a sufficient resources. This is because even though the technology and equipment used by the SMEs food industry in Surabaya are not the latest technology but still perceived good enough to be used in order to compete at the same level as large company.

Marketing resources can be defined as the average perception of the owner of SMEs food industry in Surabaya on the attributes of marketing owned and controlled by the company in order to generate sales. Marketing resources consist of company ownership of a qualified market knowledge, company access to appropriate distribution channels, and company special relationship with customers.

Based on outer loading factor, it is known that the composite variable of Marketing Resources is best reflected by the indicator of the company has a strong market knowledge, followed by the indicator of the company has access to the right distribution channel, and finally the indicator of the company has a special relationship with customers.

The food industry is a dynamic industry. Excellent market knowledge can help company to identify various factors that can affect the company. Market knowledge is a valuable information that the company has about the market. This information can consist anything, like: information about competitors, economic shifts, demographics, current market trends, characteristics of customer spending patterns, etc. Mastering and elaborating the right knowledge can encourage company to become more adaptive, innovative, smart and sustainable (Civi, 2000; Kuan \& Elaine, 2006). This is why the indicator of the company has qualified market knowledge is the best indicator in reflecting the composite variable of Marketing Resources.

Furthermore, excellent market knowledge can be used in determining the right distribution channels for company. Access to the right distribution channels can contribute greatly to customer value and create a competitive advantage for company. This is because contact, experience, specialization and operational scale owned by distribution channels can make the company's products widely available and accessible to their target market, which ultimately gives the company greater effectiveness and efficiency compare to if the company choose to work alone to build their distribution channels (Haghighinasab ,2013). This is why the indicator of the company has access to the right distribution channel is the best second indicator in reflecting the composite variable of Marketing Resources.

Finally, even though a special relationship with customers is an important factor in marketing strategies because it can create commitment and customer loyalty (Boonajsevee, 2005), but since food industry is an industry with low involvement products (Silayoi \& Speece, 2004), the company main focus should be directed at creating higher value for customers, which can be achieved through mastering and elaborating knowledge, as well as the use of appropriate distribution channels. This is why the indicator of the company has a special relationship with customers is the least indicator in reflecting the composite variable of Marketing Resources.

Based on descriptive value of respondents' answers on the composite variable of Marketing Resources, it is known that the highest indicator perceived by the respondents is the indicator of the company has a special relationship with customers, followed by the indicators of the company has access to the right distribution channel, and finally the indicator of the company have qualified market knowledge.

It can be explained that since the majority of the owners of SMEs food industry in Surabaya who were respondents in this study has established their business for more than five years, so in average they perceived that their company has been able to build personal and emotional relationships with their customers, making it easy for companies to identify the actual needs of their customers and thus serve customers in a better way. The special relationship that exists between the company and the customer makes the company already has a number of loyal customer base. The experience of doing business for more than five years also caused the company to have a wellorganized distribution channel. Connections, fame, and established market make the company has more access to 
the right distribution channels. This is why the indicator of the company have a special relationship with customers, followed by the indicator of the company has access to the right distribution channels are perceived as the two highest indicators for Marketing Resources composite variable.

The lowest indicator perceived by the owners of SMEs food industry in Surabaya is the indicator stated that the company has a qualified market knowledge. This is because the owners of SMEs food industry in Surabaya still perceived that large companies generally have broader knowledge because they have better intelligence technology compare to SMEs. However, even though it is perceived as the lowest, this indicator is still on high value, which means that it is still perceived as a sufficient resources. This is because even though large companies have intelligence technology but since the information technology growth rapidly, than it is enable the SMEs to compete at the same level as large companies. Furthermore, since they have been in business for more than five years, so it perceived that they already have enough loyal customers' base that can be used as a source of information.

\section{Conclussion}

The results of data analysis show that company's resources are best reflected by Managerial Resources, followed by Technical Resources, and last by Marketing Resources. Managerial resources play the most important role. Results of the respondents' answers indicate that on average, the owner of SMEs food industry in Surabaya assesses the resources owned by the company is on high-level. Managerial Resources is rated as the highest resources, followed by Technical Resources. While Marketing Resources is perceived as a relatively lower resources. Based on outer loading factor, it is known that the variable of Managerial Resources is best reflected by the indicator of the company has the ability to coordinate, followed by the indicator of the company has the ability to carry out strategic planning, the indicator of the company has a strong organizational culture, the indicator of the company is supported by competent managerial team, the indicator of the company is supported by skilled employees, and finally the indicator of the company has an efficient organizational structure. Based on outer loading factor, it is known that the composite variable of Technical Resources is best reflected by the indicator of the company has technical skills, followed by the indicator of the company has modern technology and equipment, and finally the indicator of the company has effective and efficient production department. Based on outer loading factor, it is known that the composite variable of Marketing Resources is best reflected by the indicator of the company has a strong market knowledge, followed by the indicator of the company has access to the right distribution channel, and finally the indicator of the company has a special relationship with customers.

\section{References}

Amit, R., \& Schoemaker, P. J. H. (1993). Strategic Assets and Organizational Rent. Strategic Management Journal, Vol. 14, pp. 33-46.

Barney, J. B, \& Hesterly, W. S. (2006). Strategic Management and Competitive Advantage: Concepts and Cases. London: Pearson Education.

Barney, J. B, \& Zajac, E. (1994). Competitive Organizational Behavior: Toward an Organizationally Based Theory of Competitive Advantage. Strategic Management Journal, Vol. 15, Special issue, pp. 5-11.

Barney, J. B. (1986). Strategic Factor Markets: Expectations, Luck, and Business Strategy. Management Science, Vol. 32, No. 10, pp. 1231-1241.

Barney, J. B. (1991). Firm Resources and Sustained Competitive Advantage. Journal of Management, Vol. 17, No. 1 , pp. $99-120$.

Barney, J. B. (1991). The Resource Based View of Strategy: Origins, Implications, and Prospects. Journal of Management, Vol. 17 (Special Theory Forum Issue), pp. 97-211.

Barney, J. B. (1995). Looking Inside for Competitive Advantage. The Academy of Management Executive, Vol. 9, No. 4, pp. 49-61.

Barney, J. B. (2002). Gaining and Sustaining Competitive Advantage. New Jersey: Prentice Hall.

Bolívar-Ramos, M., García-Morales, V., \& García-Sánchez, E. (2012). Technological Distinctive Competencies and Organizational Learning: Effects on Organizational Innovation to Improve Firm Performance. Journal of Engineering and Technology Management, Vol. 29, No. 3, pp. 331-357.

Bonaparte, W. J. (2008). The Impact of Organizational Citizenship Behavior and Organizational Commitment on Organizational Performance. Doctoral Dissertation. Nova Southeastern University.

Boon, O. K., \& Arumugam, V. (2006). The Influence of Corporate Culture on Organizational Commitment: Case Study of Semiconductor Organizations in Malaysia. Sunway Academic Journal, Vol. 3, pp. 99-115.

Boonajsevee, B. (2005). Relationship Marketing: Loyalty Intentions in New Era of Thai Bank Marketing. Thesis (DBA). Nova Southeastern University.

Boyatsiz, R. E. (2008). Competencies in the 21st century. Journal of Management Development, Vol. 27, No. 1, pp. 5-12.

Castanias, R. P., \& Helfat, C. E. (1991). Managerial Resources and Rents. Journal of Management, Vol. 17, No. 
1, pp. $155-171$.

Chiarello, T. C., Pletsch, C. S., Da Silva, A., Da Silva, T. P. (2014). Financial Performance, Intangible Assets and Value Creation in Brazilian and Chilean Information Technology Companies. Economic Review of Galicia, Vol. 23, No. 4, pp. 73-88.

Civi, E. (2000). Knowledge Management as a Competitive Asset: A Review. Marketing Intelligence and Planning, Vol. 18, No. 4, pp. 166-174.

Collinson, S., \& Houlden, J. (2005). Decision-Making and Market Orientation in the Internationalization Process of Small and Medium Sized Enterprises. Management International Review, Vol. 45, No. 4, pp. 413-436.

David, F. R. (2011). Strategic Management Concepts and Cases. London: Pearson Education.

Dierickx, I., \& Cool, K. (1989). Asset Stock Accumulation and Sustainability of Competitive Advantage. Management Science, Vol. 35, No. 12, pp. 1504-1511.

Dost, M. K. B., Ahmed, Z., Shafi, N., \& Shaheen, W. A. (2011). Impact of Organizational Commitment on Organizational Performance. Arabian Journal of Business \& Management Review, Vol. 1, No. 3, pp. 87-98.

Enright, M. J. (1995). Organization and Coordination in Geographically Concentrated Industries. In Coordination and Information: Historical Perspectives on the Organization of Enterprise. Chicago: University of Chicago Press.

Fathi, S., Farahmand, S., \& Khorasani, M. (2013). Impact of Intellectual Capital on Financial Performance. International Journal of Academic Research in Economics and Management Sciences, Vol. 2, No. 1, pp. 617.

Finkelstein, S., \& Hambrick, D. (1996). Strategic Leadership: Top Executives and Their Effects on Organizations. Minneapolis: West Publishing Company.

Ghorbanhosseini, M. (2013). The Effect of Organizational Culture, Teamwork and Organizational Development on Organizational Commitment: The Mediating Role of Human Capital. Technical Gazette, Vol. 20, No. 6, pp. 1019-1025.

Gomez-Mejia, L. R., \& Balkin, D. B. (2002). Management. New York: McGraw-Hill.

Grant, R. M. (1991). The Resource-Based Theory of Competitive Advantage: Implications for Strategy Formation. California Management Review, Vol. 33, No. 3, pp. 114-35.

Grant, R. M. (1996). Toward a Knowledge-Based the Theory of the Firm. Strategic Management Journal, Vol. 17 (Winter Special Issue), pp. 109-122.

Hafsah, M. J. (2004). Upaya Pengembangan Usaha Kecil dan Menengah. Buletin Infokop, Nomor 25, Tahun XX, pp. 20-24.

Haghighinasab, M., Ebrahimi, M. Sattari, B., \& Roghanian, P. (2013). The Effect of Channel Function Performance on Relationship Quality with Organizational Buyers: A Case Study in Iranian Food Distribution Company. International Journal of Fundamental Psychology and Social Sciences, Vol 3, No.3, pp. $42-47$

Hambrick, D. C., \& Mason, P. A. (1984). Upper Echelons: The Organization as a Reflection of Its Top Management. Academy of Management Review, Vol. 9, pp. 193-206.

Harrison, J. S., \& St. John, C. H. (1994). Strategic Management of Organizations and Stakeholders. Minnesota: West.

Hayes, R. H., \& S. C. Wheelwright. (1984). Restoring Our Competitive Edge: Competing Through Manufacturing. New York: John Wiley.

Henderson, R., \& Cockburn, I. (1994). Measuring Competence? Exploring Firm Effects in Pharmaceutical Research. Strategic Management Journal, Vol. 15 (Special Issue), pp. 63-84.

Hitt, M. A., Ireland, R. D., \& Hoskisson, R. E. (2001). Strategic Management. Competitiveness and Globalization. Bloomington: South-Western College Pub.

Hitt, M. A., Ireland, R. D., Camp, S. M., \& Sexton, D. L. (2001). Strategic Entrepreneurship: Entrepreneurial Strategies for Wealth Creation. Strategic Management Journal, Vol. 22, No. 6, pp. 479-492.

Huo, B. (2012). The Impact of Supply Chain Integration on Company Performance: An Organizational Capability Perspective. Supply Chain Management: An International Journal, Vol. 17, No. 6, pp.596-610.

Husband, S., \& Purnendu, M. (1999). A Conceptual Model for Quality Integrated Management in Small and Medium Size Enterprise. International Journal of Quality \& Reliability Management, Vol. 16, No. 7, pp. 699713.

Irefin, P., \& Mechanic, M. A. (2014). Effect of Employee Commitment on Organizational Performance in Coca Cola Nigeria Limited Maiduguri, Borno State. IOSR Journal of Humanities \& Social Science, Vol. 19, No. 3, pp. 33-41.

Itami, H. (1987). Mobilizing Invisible Assets. Massachusetts: Harvard University Press.

Kashefi, M. A., Mahjoub, A. R., Rahimi, G. A. H., Hesabi, A. M. B., Keshavarz, M. H., \& Nadimi, G. (2013). Organizational Commitment and Its Effects on Organizational Performance. Interdisciplinary Journal of Contemporary Research in Business, Vol. 4, No. 12, pp. 501-510.

Katz, R. L. (1974). Skills of an Effective Administrator. Harvard Business Review Vol. 52, pp. 90-102. 
Kautsar, I, F. (2011). Knowledge Management sebagai Keunggulan Kompetitif pada Usaha Kecil Menengah (UKM): Implementasi dan Hambatannya, diunduh dari http://ikhlas35e.blogstudent.mb.ipb.ac.id/files/2011/01/Knowledge-Management-Sebagai-KeunggulanKompetitif-Bagi-UKM-_-Implementasi-dan-Hambatannya.pdf retrrieved on 15 January 2017.

Kramer, R. M. (2010). Trust Barriers in Cross-Cultural Negotiations: A Social Psychological Analysis. In: Organizational Trust: A Cultural Perspective. Cambridge: Cambridge University Press.

Kuan, Y. W., \& Elaine, A. (2006). Development of a Knowledge Management Initiative and System: A Case Study. Expert Systems with Applications, Vol. 30, pp. 633-641.

Latifi, M., \& Shooshtarian, Z. (2014). The Effects of Organizational Structure on Organizational Trust and Effectiveness. Polish Journal of Management Studies, Vol. 10, No. 2, pp. 73-84.

Lauture, R., Amewokunu, Y., Lewis, S., \& Lawson-Body, A. (2012). Impact of Culture on the Organizational Commitment of Public-Sector Employees in Haiti. International Business \& Economics Research Journal, Vol. 11, No. 3, pp. 331-342.

Lev, B. (2001). Intangibles-Management, Measurement and Reporting. Washington: Brookings Institution Press. Lewis, R. D. (2006). When Cultures Collide: Leading Across Cultures. Boston: Nicholas Brealey International.

Mahemba, C. M. (2003). Innovation Management Practices of Small and Medium Scale Enterprises in Tanzania. Doctoral Dissertation, University of Twente.

Mahoney, J. T., \& Pandian, J. R. (1992). The Resource-based View within the Conversation of Strategic Management. Strategic Management Journal, Vol. 13, No. 5.

Manetje, O., \& Martins, N. (2009). The Relationship between Organizational Culture and Organizational Commitment. Southern African Business Review, Vol. 13, No. 1, pp. 87-111.

Norburn, D., \& Birley, S. (1988). The Top Management Team and Corporate Performance. Strategic Management Journal, Vol. 9, pp. 225-237.

Ozcelik, G., \& Ferman, M. (2006). Competency Approach to Human Resources Management:Outcomes and Contributions in a Turkish Cultural Context. Human Resource Development Review, Vol. 5, No. 1, pp. 7291.

Pate, J., Martin, G., \& Robertson, M. (2003). Accrediting Competencies: a Case of Scottish Vocational Qualifications. Journal of European Industrial Training, Vol. 27, No. 2-3-4, pp. 169-176.

Penrose E. (1959). The Theory of the Growth of the Firm. New Jersey: John Wiley \& Sons.

Peteraf, M. A, \& Barney, J. (2003). Unraveling the Resource-Based Tangle. Managerial and Decision Economics, Vol. 24, pp. 309-323.

Peteraf, M. A. (1993). The Cornerstones of Competitive Advantage: A Resource-Based View. Strategic Management Journal, Vol. 14, No. 3. pp. 179-191.

Salama, I. E. E. (2017). The Impact of Knowledge Management Capability, Organizational Learning, and Supply Chain Management Practices on Organizational Performance. The Business and Management Review, Vol. 8, No. 5, pp. 37-51.

Silayoi, P., \& Speece, M. (2004). Packaging and Purchase Decisions an Exploratory Study on the Impact of Involvement Level and Time Pressure. British Food Journal, Vol. 106, No. 8, pp. 607-628.

Spanos, Y., \& Lioukas, S. (2001). An Examination into The Causal Logic of Rent Generation: Contrasting Porter's Competitive Strategy Framework And The Resource-Based Perspective. Strategic Management Journal, Vol. 22, No. 10, pp. 907-934.

Spanos, Y., Zaralis, G. \& Lioukas, S. (2004). Strategy and Industry Effects on Profitability: Evidence from Greece. Strategic Management Journal, Vol. 25, pp. 139-165.

Tambunan, T. (2005). Promoting Small and Medium Enterprises with a Clustering Approach: A Policy Experience from Indonesia. Journal of Small Business Management, Vol. 43, No. 2, pp.138-154.

Tambunan, T. (2008). Masalah Pengembangan UKM di Indonesia: Sebuah Upaya Mencari Jalan Alternatif, Bahan diskusi Forum Keadilan Ekonomi (FKE) Institute for Global Justice, Jakarta, 28 September 2008, diunduh dari http:/www.kadin-indonesia.or.id/enm/images/dokumen/KADIN-98-3144-26092008.pdf retrrieved on 15 January 2017.

Tambunan, T. (2010). Ukuran Daya Saing Koperasi dan UKM. Backgound studi RPJM Nasional 2010 - 2014 , Bidang Pemberdayaan Koperasi dan UKM, Bappenas, diunduh dari http://www.kadinindonesia.or.id/enm/images/dokumen/KADIN-98-3000-21072008.pdf retrrieved on 15 January 2017.

Teixeria R., Koufteros X., \& Peng X.D. (2012). Organizational Structure, Integration and Manufacturing Performance: A Conceptual Model and Propositions. Journal of Operation and Supply Chain Management, Vol. 5, No. 1, pp. 69-81.

Tsai, C., Lu, Y., \& Yen, D. C. (2012). Determinants of Intangible Assets Value: The Data Mining Approach. Knowledge-Based Systems, Vol. 31, pp. 67-77.

Utterback, J. (1994). Mastering the Dynamics of Innovation. Boston: Harvard Business School Press.

Viinamäki, O. (2004). A Theory of Coordination and Its Implication on EU Structural Policy: A Comparative 
Study of the Challenges for Coordination in Structral Funds in Finland, Ireland and Sweden. Administrative Science No. 132. Vaasa: University of Vaasa/Publication Unit.

Wernerfelt, B, \& Montgomery, C. A. (1988). Diversification, Ricardian Rents, and Tobin's q. RAND Journal of Economics, Vol. 19, No. 4, pp. 623-632.

Wernerfelt, B, \& Montgomery, C. A. (1988). Tobin's Q and the Importance of Focus in Firm Performance. The American Economic Review, Vol. 78, pp. 246-250.

Wernerfelt, B. (1984). A Resource-based View of the Firm. Strategic Management Journal, Vol. 5, No. 2, pp. 171180.

Widiastuti, E., \& Sulistyandari. (2013). Peningkatan Daya Saing UKM melalui Peran Modal Intelektual dan Kinerja Keuangan, diunduh dari http://jp.feb.unsoed.ac.id/index.php/sca-1/article/viewFile/302/307 retrrieved on 15 January 2017.

Xu, D., Huo, B., \& Sun, L. (2014). Relationships between Intra-Organizational Resources, Supply Chain Integration and Business Performance: An Extended Resource-Based View. Industrial Management and Data Systems, Vol. 114, No. 8, pp. 1186-1206.

Zain, Z. M., Ishak, R., \& Ghani, E. K. (2009). The Influence of Corporate Culture on Organizational Commitment: A Study on a Malaysian Listed Company. European Journal of Economics, Finance \& Administrative Sciences, Vol. 17, pp. 16-26. 